\title{
Organizational Measures as Key Factors to Success in E-Learning on Corporate Intranet: The Case of a Company in Cameroon
}

\author{
Tchuente Monique ${ }^{1} \&$ Wamba Henri ${ }^{1}$ \\ ${ }^{1}$ Faculty of Economics and Management, University of Yaounde II, Yaounde, Cameroon \\ Correspondence: Tchuente Monique, Faculty of Economics and Management, University of Yaounde II, \\ Yaounde, Cameroon. Tel: 237-99-865-613. E-mail: motchuen@yahoo.fr
}

\author{
Received: October 10, $2014 \quad$ Accepted: November 5, $2014 \quad$ Online Published: November 24, 2014 \\ doi:10.5539/ijms.v6n6p118 URL: http://dx.doi.org/10.5539/ijms.v6n6p118
}

\begin{abstract}
This article studies the key factors underpinning the success of e-Learning on corporate intranet. Indeed, theoretically, e-Learning has many avantages such as time and location flexibility for learners and teachers, the possibility to personnalize the learning process, the potential for establishment of a community of collaboration between learners and facilities for assessing and monitoring them. However in practice, e-Learning projects post rather mixed outcomes and record very high dropout rates. This raises the question of the key factors that influence the success of corporate e-Learning projects. To address this concern in the particular case of corporate intranet e-Learning projects, we have proposed a theoretical framework that combines the Davis model for user acceptance of a technology, and the Brillet model for effective implementation thereof. Our analysis shows clearly that organizational measures are key factors for the success of e-Learning projects. This theoretical result is confirmed by an experimental study to introduce e-learning in a company in Cameroon.
\end{abstract}

Keywords: e-Learning, company, intranet, technology, user acceptance, ownership, organizational factors

\section{Introduction}

Today, there is widespread use of information and communication technologies (ICTs) by businesses. Indeed, in a rapidly changing world marked by a globalization of markets, rapid technological progress and an increasingly competitive environment, ICTs have become an indispensable tool for companies to improve their performance. In fact, the key to building a successful business lies in securing appropriate infrastructure to optimize various processes. When a company understands how it can use ICTs to link together information throughout the organization, it can adjust its processes to improve knowledge sharing internally and respond more effectively to customer requirements (OECD, 2003).

One manifestation of corporate keen interest for ICTs is the development of e-Learning for continuing personnel training. This method of training is defined as "a complex and dynamic set of educational resources on digital media, together with technological resources and services that mobilize users with varying skills to enable them achieve their career in an independent, personalized and responsible manner "(Nganmini, 2009). E-Learning allows flexible schedules and removes the constraint of unique place for learners and trainers. Moreover, it has the potential to personalize the learning process and build communities of collaboration between learners. Lastly, it affords facilities for the evaluation and monitoring of learners. E-Learning appears as a solution that can meet the challenges of continuing training in companies where the staff is large, has a variety of profiles and is spread in the agencies within a country or even in branches in several countries.

However, the effectiveness of this training system is still under debate. While for some researchers e-Learning offers a competitive advantage and constitutes an unquestionable success story, others point to hidden costs, resistances to change, the relatively high failure rate (between 30 and $85 \%$ according to various studies), and weak performances (Dossou, 2010).

This gap between the theoretical performance of e-Learning and the results obtained on the field raises questions about barriers impeding its effectiveness. This is an important issue because firms that engage in e-Learning often have to make large investments both on the platform and on contents design against a backdrop of high uncertainty on account of the risk of failure. Many studies have addressed this question, though to our knowledge, none has specifically focused on the case of projects where access to the e-Learning platform is 
restricted to a company's internal network also referred to as intranet. Yet this is the prevailing situation in most African companies which, for security reasons, restrict access to their servers in order to protect themselves against cyber attacks whose consequences can be disastrous. This access constraint invalidates one of the major advantages of e-learning, namely the opportunity for learners to work on the platform and access resources or communicate with others, irrespective of their locations. Moreover, this constraint of physical presence within the company to be able to learn online is a source of potential conflict with professional activities.

In light of the foregoing, our research question is as follows: what are the most decisive factors underpinning the success of an e-learning project conducted on corporate intranet? The answer to this question will be a valuable guide for decision makers engaging in such projects. Indeed, they are faced with multiple challenges linked to infrastructure, information systems, learning contents and organizational aspects. Accordingly, they need to know what the most critical factors of success are, in order to concentrate their efforts thereon.

Our research is based on an inductive approach. For this purpose, we begin by presenting in section 2 the theoretical framework adopted to measure the effectiveness of an e-Learning project, namely ownership. We then conduct an empirical study on a Cameroonian company. The sources of data and the methodology adopted for our analysis are presented in section 3 while the results are presented in section 4 . Section 5 is devoted todiscussion and the conclusion is presented in section 6 .

\section{Theoretical Framework}

For a company, measuring the effectiveness of training goes beyond the acquisition of knowledge. Such measurement must take into account the learner's ability to apply acquired knowledge to his work. Ownership thus appears as the right conceptual framework. According to Proulx (2005), ownership is defined as "the process of gradual inculcation of requisite technical and cognitive skills in individuals and groups engaged in technical use of technologies". This author then identifies four conditions necessary for ownership apart from access: technical and cognitive mastery of the artifact, meaningful integration of the technical object in daily practice, the possibility of creating new uses and, at a more collective level, social ownership. Considering the central role played by ICTs in e-Learning, our theoretical framework will be based on models of ownership of a technology.

\subsection{Technology Ownership Model}

The concept of ownership has two main ideas. The first idea here is user acceptance defined as the desire to adopt a given behavior. Ownership itself refers to methods of domestication that transform a foreign object into a familiar one. Thus the individual adapts the technical object to his use by fashioning it. The culmination of this process is personalization since the individual is able to own it.

It is in this relationship of passage from explicit, codified and communicable knowledge in a formal and systematic language, to tacit and transformed knowledge rooted in action or in a specific context, that ownership takes place.

In short, the adoption of a technology refers to a series of events leading to its acceptance, while ownership refers to effective and personalized use of the technology.

In this article, we determine the acceptance of e-learning using the technology acceptance model developed by Davis (1989). Regarding ownership itself, we use the Brillet et al (2010) model adapted from the pragmatic and semiotic theory of tools developed in (Lorino 2002).

\subsection{E-Learning Adoption Model on Corporate Intranet}

According to Davis (1989), acceptance of a technology depends on two factors: perceived usefulness and perceived ease of use. The perceived usefulness is defined as the degree to which a person believes that the use of a system will improve his performance. It reflects the perception of the performance gains to be achieved by the user of a technology. For its part, perceived ease of use is defined as the intensity with which an individual believes that using a particular system will be without difficulties and will not require an extra effort. According to the Davis theory, these two dimensions make it possible to understand user acceptance. This confirms the conclusions of previous studies such as those of (Szajna 1994) about the power of these factors as determinants of user acceptance of new technologies.

In the case of continuing education in companies, the face-to-face formula generally has many benefits for staff. First, it is most often done during a fixed period with stoppage of work, thus permitting the learners concerned to be relieved for a time from the often intense work pace and to relax. Moreover, when the training is delocalized, the venue is often a pleasant sea-side resort hotel or castle in the countryside. Finally, in the specific case of 
African companies, delocalization is accompanied by mission allowances that constitute additional income.

By contrast, e-Learning does not have these advantages. Worse still, e-Learning leads to work overload since there is no work stoppage. To promote adoption of e-Learning therefore, it is necessary to provide incentives that offset its disadvantages compared to face-to-face training.

Accordingly, Venkatesh et al. (2003) introduced a determinant which, in what these authors call a unified theory of acceptance and use of technology, involves several factors, two of which relate to incentives: "the relative advantage" defined as the "degree to which an innovation is perceived as offering a greater advantage over the one it is replacing" and the "extrinsic motivation" that reflects an exchange between the individual and the organization through rewards granted. Such incentives motivate company employees to accept training (Tremblay \& De Sève, 2005). For example, Lauzon (2003) stated that in Québec companies, several reasons for adopting e-learning appear to be linked to rewards such as secure jobs, increased remuneration or career promotion. In a study on the introduction of a medical technology system, Massaro (1993) argues that the absence of any perceived short-term benefit for professional medical staff resulted in a lack of commitment to the system put in place. Other studies on the importance of incentives for the success of online training projects can be found in (Gagnon, 2003).

Another variable which may favor technology acceptance is awareness. In fact, since e-Learning is not a familiar method of training, learners have to be sensitized. While young people conversant with new technologies easily use computers, the same cannot be said of older employees some of whom are in the twilight of their careers. Under these conditions, awareness is even more necessary to roll back some resistances. The human resources department must educate learners by demonstrating the usefulness and necessity of the new training method.

\subsection{E-Learning Ownership Model on Corporate Intranet}

Ownership of an innovation can be defined as a process that facilitates mastery of its effective implementation (Lauzon, 2003). In this case, it is the passage from intention to actual implementation that creates a link between acceptance and ownership. To this effect, Brillet et al. (2010) propose that we start with the acceptance intention, analyze the process of effective use and assign it meanings and specific functions.

This theory allows us to take into account social and psychological logics generated by the introduction of a new technology, in addition to the pure technical aspects linked to the intrinsic properties of the tool. Hence, ownership is viewed as the process by which a user interacts with other individuals to reconstruct for himself a system of usage patterns. Brillet et al. introduce interpretation schemes which use interpretation registers that can be rational, socio-political or psycho-cognitive. This process leads the user to assign the tool functions that may be prescribed, non-prescribed or symbolic.

The main criticism that can be leveled against the instrumental theory is that it does not take into account organizational aspects that also have an impact on ownership and can foster or impede it. Different authors have highlighted a number of organizational factors that are determinants of technological acceptance in healthcare organizations (Gagnon, 2003). Furthermore, Demissy (2003) notes that very often one reason for the failure of corporate e-learning is the lack of administrative support by hierarchy.

In our case, restriction to intranet for access to the platform is a constraint that invalidates the advantages of e-Learning linked to flexibility of place for learning activities. Indeed, the training is done at the workplace, which requires readjustment of working schedules in order to allocate time for e-Learning. In the particular case of employees working on production lines, it means replacing them. As a result, it is important to eschew the trap of considering e-learning as simply an additional activity to normal workload because the resulting work overload can hardly be bearable. To ensure a calm atmosphere necessary for concentration, training rooms must be equipped with adequate workstations. Also, the possibility for employees to get training without time constraints requires the provision of educational resources in printed form or better still in digital format. In the case of digital media, it will be important to remove restrictions linked to software licenses by adopting upstream a policy of free software for all support software.

Moreover, the organization of tutoring, especially for synchronous sessions, requires that tutors should have access to the intranet. This requires them to travel which must be taken into account and, for the company, the issuance to them of access authorizations. Finally, to allow for permanent communication between tutors and learners, a parallel communication system should be considered: messaging via public providers or use of individual devices such as mobile phones.

It is therefore clear that in the context of restricted access via corporate intranet, there are specific organizational steps the company must take to ensure the success of e-Learning, failing which the project is likely to abort 
regardless of the arrangements made in respect of network infrastructure, equipment or contents mediation. The conceptual framework we have adopted for ownership of e-Learning on company intranet combines the Davis model for acceptance, supplemented by incentives and awareness and, on the other hand, the Brillet et al model for ownership to which we have added organizational measures. Our framework is presented in Figure 1 wherein rectangular elements stand for factors, oval elements for processes while the round elements represent either results produced or consequences.

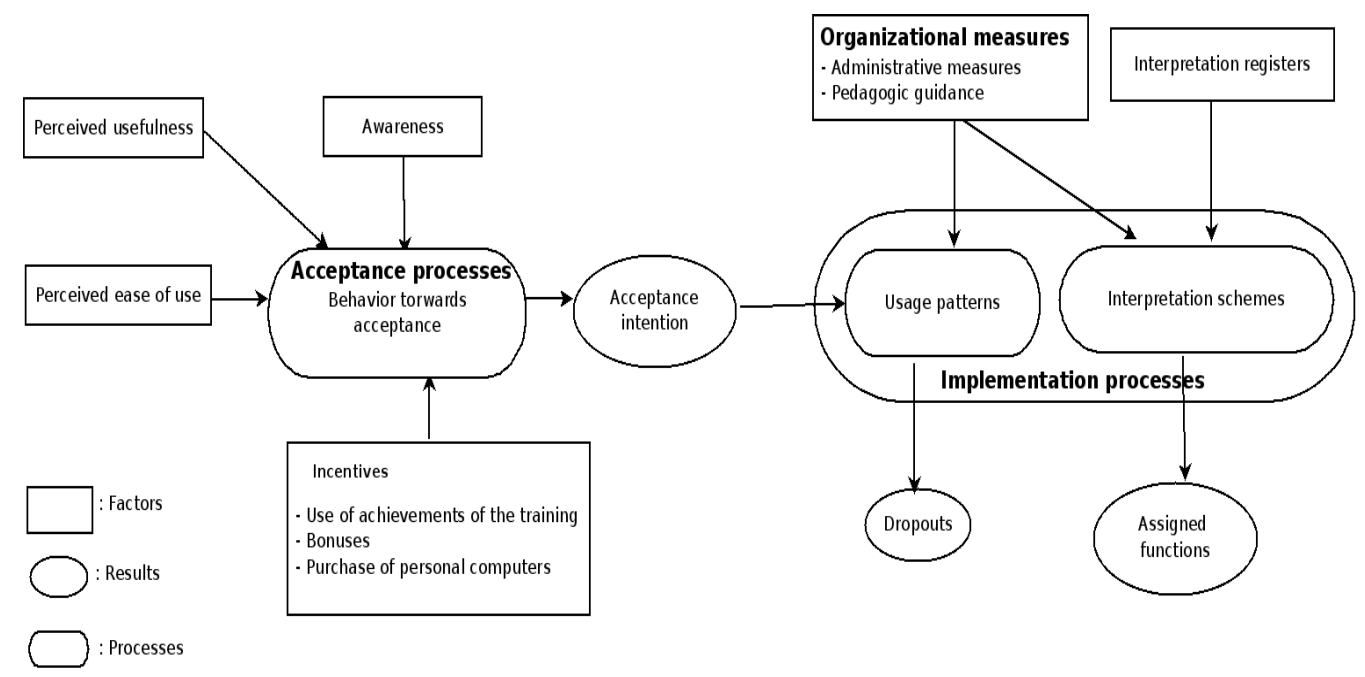

Figure 1. Model of e-Learning ownership on corporate intranet

\section{Empirical Study: Introduction of E-Learning in a Cameroonian Company}

In this section, we present an empirical study on a company in Cameroon. We will omit here any information likely to undermine the privacy of the company referred to herein as ICT Champion.

\subsection{Context of the Study}

After heavy investments to interconnect its dozen agencies and distribution centers, followed by the purchase of equipment such as servers and workstations, ICT Champion initiated significant structural and organizational reforms some of which are related to implementation of Enterprise Resource Planning (ERP). In 2010, the Company was faced with an upsurge in training needs. To enable its staff take advantage of opportunities arising from modernization of its information system, its managers opted to shift from face-to-face training to online training, which they considered as appropriate to consolidate and optimize knowledge management as well as improve the company's overall performance.

The e-Learning project then came to birth, with the aim of reducing in the short-term costs relating to training in office software and ERP and, in the medium-term, to deploy this solution to trades training. Accordingly, external expertise was recruited to develop a platform based on the Moodle open source software, design contents and provide training in office software and, lastly to adapt to the e-Learning platform, the ERP courses designed by internal experts. Office software courses were then conducted online in the last quarter of 2011 and during 2012. At the same time, the platform was used as a medium to organize face-to-face training in ERP.

\subsection{Conduct of the Online Training Sessions}

The training sessions took place in two stages: one meeting day followed by two weeks of online training under the guidance of different tutors. The company's general policy was to authorize access to its information systemonly throught the corporate intranet, which was a major constraint for both the learners and tutors.

The objective of the one-day meeting was to present the modalities of online training, the platform and the office software program. After that day, learners assessed the quality of the platform and of the performance of tutors handling the meeting phase.

Online training took place over six working days, with a synchronous tutoring session every other day. At the end of this step, a final evaluation was organized for the entire program.

Coordination meetings were held quarterly between external service providers responsible of training in office 
software and human resource managers, to assess the progress of the project and possibly take corrective actions.

\subsection{Sources of Data}

Evaluations after meetings and at the end of training included an open-comments section to afford learners the opportunity to express their opinions freely. In addition, 7 (seven) tutors were required to write a report at the end of each session on their observations and remarks. These remarks concerned attendance and difficulties encountered. Assessments, tutors' reports, minutes of coordination meetings as well as the free platform exchanges between learners and tutors, constituted our primary sources of data. Note that the platform automatically generates statistics on attendance, dropouts and success rates.

The second source of information consisted in interviews with office software tutors and the ERP trainer. This enabled us to gather information about the quality of the organizational measures taken in different centers. Furthermore, the ERP trainer gave us valuable information on the importance of the platform during face-to-face sessions and in monitoring learners after their training.

The third source of information consisted in interviews with human resource managers within the company. This allowed us to better understand specificities of certain groups in terms of level and motivation of learners as well as some organizational difficulties. For example, some extremely high absence rates corresponded to groups of learners made up of commercial staff that have to meet a significant proportion of their target by the end of the year and cannot therefore be compelled to physically attend synchronous training sessions in the company, given the access constraint via company intranet.

\subsection{Information Analysis Methodology}

We adopted the qualitative approach to describe the different factors identified in the ownership model. Indeed, since we are in the context of corporate training, it is necessary to understand the detailed description of events, people and their interactions in order to better apprehend the situation. Only qualitative methods can enable us perform such analyses (Gagnon, 2012).

By contrast, analysis of the impact of factors on acceptance intention and ownership is done using a data mining technique commonly used in computer science. Specifically, we used the classification technique to determine the variable with the greatest impact on acceptance intention. This technique that is explained in the appendix produces results that are easy to interprete. Indeed, let us assume that two variables $\mathrm{X}$ and $\mathrm{Y}$ are measured out of a population. When the variable $\mathrm{X}$ is used to explain the variable $\mathrm{Y}$, the impact of $\mathrm{X}$ on $\mathrm{Y}$ is the number of correct predictions. In this approach, when $\mathrm{X}$ takes a given value $\mathrm{x}$, the prediction made for value $\mathrm{Y}$ is the majority value taken by $\mathrm{Y}$ in the sub-population consisting of entities with the $\mathrm{x}$ value for the $\mathrm{X}$ variable.

\section{Results}

We will start by analyzing the results of acceptance intention and its determinants.

\subsection{Results for the Intention of Adoption}

Statistical data on training conducted in office software during the period under study are presented in Table 1 below.

Table 1. Statistics of training in office software

\begin{tabular}{llll}
\hline Center & Number registered & Number present in the center & Number present in the final result \\
\hline A & 62 & $56(90.3 \%)$ & $43(76.8 \%)$ \\
B & 72 & $52(72.2 \%)$ & $28(53.8 \%)$ \\
C & 35 & $35(100 \%)$ & $34(97.1 \%)$ \\
D & 173 & $122(70.5 \%)$ & $41(33.6 \%)$ \\
E & $128(57.9 \%)$ & $74(57.8 \%)$ \\
\hline TOTAL & 521 & $393(69.8 \%)$ & $220(56 \%)$ \\
\hline
\end{tabular}

In this table, we see that 563 people spontaneously enrolled for training in office software. Now, since training was done after a phase of sensitization and information about e-Learning, we believe that the 393 people who showed up for the meetings are those with a positive acceptance intention.

In evaluating the acceptance intentions per center, we adopted a scale of three values: ' ++ ' when the attendance rate was over $90 \%$, '+' when the rate was between $70 \%$ and $89 \%$, and '-' for all other cases. We then obtained the last column of Table 2 as seen below. 
Table 2. Variables explaining the e-Learning acceptance intention

\begin{tabular}{llllll}
\hline Centers & $\begin{array}{l}\text { Perceived } \\
\text { usefulness }\end{array}$ & $\begin{array}{l}\text { Perceived ease } \\
\text { of use }\end{array}$ & Incentives & Awareness & Acceptance intention \\
\hline A & - & - & - & ++ & ++ \\
B & - & - & - & + & + \\
C & ++ & ++ & + & ++ & ++ \\
D & - & - & - & - & - \\
E & - & - & - & -- & 5 \\
\hline Explanatory power & 3 & 3 & 3 & 5 & \\
\hline
\end{tabular}

According to Figure 1, the factors explaining the acceptance intention are perceived usefulness, perceived ease of use, incentives and awareness.

Regarding perceived usefulness, it should be noted from the outset that e-learning as a training mode, replaces the face-to-face mode. In all centers except center $\mathrm{C}$, the extracts show that almost all students demanded longer meeting periods. Besides, by the end of the training, there was virtually no positive feedback on the benefits of online training as compared to the classroom formula. So we can conclude that the perceived usefulness of e-learning as a training mode is negative (-) for centers A, B, D and E. Conversely, the human resource manager for center $\mathrm{C}$ explained in interviews that most of the employees of the center were under-classified with respect to their level of education. As a result, they perceived e-Learning as an opportunity to more easily and autonomously acquire new skills likely to cause their reclassification within the company. So we can say that for them the perceived usefulness is very positive $(++)$. The evaluation of the perceived usefulness for all centers corresponds to column two of Table 2.

Concerning perceived ease of use, center $\mathrm{C}$ distinguishes itself from the others. First, according to the human resource manager, the majority of employees at the center had an initial qualification of at least $\mathrm{A} /$ Level +2 years of University studies. Moreover, they already had good knowledge of computing which is used in most operations in the center. For them the perceived ease of use is very positive $(++)$. For other centers, discussions with tutors and comments contained in extracts revealed genuine fears about online training. According to the human resource managers of these centers, many registered learners did not know how to use a computer.The fact that e-Learning requires minimal technical knowledge to access resources made them have a negative perceived ease of use. This was exacerbated by the self-training aspect, which they were not used to in their continuing training activities. In this regard, many learners in these centers had this to say notably:

- We need two days of meetings because physical contact permits beneficial exchanges for the learner.

- For novices like us, it would have been necessary to have more than one day with the instructor in face-to-face training sessions.

- The e-Learning platform is new for us and so we need more practice and time to master it perfectly.

We can thus conclude that except for center C, perceived ease of use is negative (-) for all centers. Column 3 of Table 2 shows user-perception evaluation for all centers.

On incentives, center $\mathrm{C}$ stands out again. Indeed, on account of the tacit level of competition in this center for access to better positions within the company, e-Learning appears as an innovation whose adoption is an added value that enriches the learner's profile and opens prospects for career advancement. Tutors' comments confirm the active participation of learners in training:

- $\quad$ All students were present and despite the tiredness, they demonstrated remarkable patience and attentiveness.

- Learners have so far demonstrated real commitment to master Excel 1 and at least 3/5 of them already wish to apply for Excel 2. One of the learners has indeed made remarkable progress even though he works only at night.

So we can say that this particular site creates a positive incentive $(+)$ for acceptance of online training. In other centers, we observed no positive motivation or incentive for e-Learning in tutors' comments or during interviews with human resource managers. For employees of these centers, e-learning is seen just as an alternative in the organization of continuous training with its own new challenges and even with some drawbacks compared to classroom training. Among the drawbacks mentioned covertly, we note the loss of leisure days and travel allowances.

With regard to awareness, human resource managers told us that it was conducted very efficiently in centers with limited staff number such as centers A and C, that is at the level '++'. For center E, awareness was very difficult 
not only because of geographical distribution (7 sub-centers spread in four regions) but also because of the diversity of structures (general management, factories, distribution centers). Its awareness level is thus very negative (- -). For center D that covers three regions, awareness was difficult because of communication problems, though better than for center E, and we attribute it the level '-'. For center B, the level of awareness is ' + '. The evaluation of the level of awareness for all centers is captured in column 5 of Table 2.

Based on the method explained in the appendix, we calculated the explanatory power of each acceptance intention factor. The result is given in the last row of Table 2 and it is clear that awareness is the factor with the greatest impact on acceptance intention.

\subsection{E-Learning Ownership Results}

In this section, we present the results of the implementation process. In the theoretical framework illustrated in Figure 1, this process has two components: the effective use of technology and interpretations. We begin by specifying success indicators.

For effective use, the dropout rate is a good indicator. Table 3 shows three categories of centers: centers A and C where the dropout rate is less than $25 \%$ (indicator ' + '), centers B and $\mathrm{E}$ where dropout rate lies between 25 and $50 \%$ (indicator ' - ') and finally center $\mathrm{D}$ where dropout rate is $66.4 \%$ (indicator '-.-'). These indicators show that the first phase of ownership that concerns effective use of e-learning, is positive in centers A and $\mathrm{C}$, negative in centers $\mathrm{B}$ and $\mathrm{E}$ and very negative in center $\mathrm{D}$. See Table 3 below.

Table 3. Dropout rate

\begin{tabular}{llllll}
\hline Centers & A & B & C & D & E \\
\hline Dropout rate during training & $23.2 \%$ & $46 \%$ & $2.8 \%$ & $66.4 \%$ & $42 \%$ \\
Indicated values & + & - & + & -- & - \\
\hline
\end{tabular}

Factors in this section essentially concern organizational measures. Table 4 below provides a summary of tutors' assessments of the different centers.

Table 4. Summary of tutors' assessments

\begin{tabular}{llllll}
\hline \multicolumn{1}{c}{ Centers } & A & B & C & D & E \\
\hline Learner monitoring by the HR department & ++ & + & ++ & - & -- \\
Prior information of superiors & ++ & + & ++ & -- & - \\
Punctuality of learners & ++ & + & ++ & -- & -- \\
Availability of machines & ++ & - & ++ & + & - \\
Internet access & + & - & ++ & - & - \\
Re-adjustment of work load & -- & -- & -- & -- & -- \\
Availability of good software versions & ++ & - & ++ & - & - \\
Availability of course materials on paper & ++ & - & ++ & - & + \\
Other logistical arrangements & ++ & - & ++ & -- & + \\
\hline General Appraisal & ++ & - & ++ & -- & - \\
\hline
\end{tabular}

Supervision by the human resource department (lines 1,2), material organization (lines 4, 5, 7, 8) and logistical arrangements (line 9) were very effective in centers A and C with limited staff numbers. This may explain why the punctuality is very high for these centers (line 3). By contrast, in large centers such as D and E, which cover three and four regions respectively, with very low internet coverage, learners experienced real difficulties in the online learning phase. For instance, participation in synchronous tutoring sessions necessitated long travels to access the platform via the company intranet. In center D, many learners were workers engaged in the production, with watchkeeping duties. Some of them complained about having to participate in synchronous sessions immediately after their service, with no time to rest, and others complained about the noise of machines because they had to hook up from workstations installed in the workshop. No center carried out a re-adjustment of work load (line 6).

Upon analysis of the dropout indicator in the last row of Table 3 and the overall situation in the last row of Table 4, it emerges clearly that:

- $\quad$ Centers A and C with the '++' score for organizational measures have the lowest dropout rates; 
- Center D with the lowest rating for organizational measures has the highest dropout rate, with $66 \%$;

- Centers B and E, which also experienced organizational difficulties, though to a lesser extent than center D, have dropout rates of $46 \%$ and $42 \%$ respectively.

This shows that organizational measures are strongly correlated with dropout rates and therefore have a strong impact on ownership.

With regard to interpretation registers and assigned functions, there is no significant difference between the centers. Table 5 below provides a summary of the global analysis for all centers. Extracts are shown in column 1. The interpretation registers and assigned functions are presented in column 2. Column 3 gives the corresponding dimension of e-Learning. The value of the ownership indicator that summarizes the information of the first three columns is presented in column 4 . Thislast column shows a balance between positive and negative values. So we can say that for this project, interpretation registers and assigned functions do not constitute key explanatory factors for ownership. Consequently, the low e-Learning ownership in the company linked to the organizational factors discussed earlier on.

Table 5. Learner's comments

\begin{tabular}{|c|c|c|c|}
\hline EXTRACTS & $\begin{array}{l}\text { Interpretation registers \& assigned } \\
\text { functions }\end{array}$ & $\begin{array}{l}\text { e-learning } \\
\text { dimension }\end{array}$ & Indicator value \\
\hline $\begin{array}{l}\text { The program has enabled us to acquire elements } \\
\text { to continue training at our workstations }\end{array}$ & psycho cognitive register prescribed function & Self - training & + \\
\hline $\begin{array}{l}\text { e-Learning is a good initiative that converges us } \\
\text { with modernity }\end{array}$ & socio political register prescribed function & Modernity & + \\
\hline This platform allows good interactivity & rational register prescribed function & Interactivity & + \\
\hline It's not always easy to work alone & $\begin{array}{l}\text { psycho cognitive register unprescribed } \\
\text { function }\end{array}$ & Self- training & - \\
\hline $\begin{array}{l}\text { We need meetings because nothing can replace } \\
\text { human contact. }\end{array}$ & sociopolitical register Unprescribed Function & Distance training & - \\
\hline $\begin{array}{l}\text { Provide opportunities for learners to be assisted } \\
\text { by phone because there are often crashes. }\end{array}$ & $\begin{array}{l}\text { psycho cognitive Register } \\
\text { Unprescribed function }\end{array}$ & Tutoring & - \\
\hline $\begin{array}{l}\text { e-Learning is interesting, but we want a direct } \\
\text { application in to our area of activity. }\end{array}$ & $\begin{array}{l}\text { psycho cognitive Register } \\
\text { Unprescribed function }\end{array}$ & Utility & - \\
\hline $\begin{array}{l}\text { e-Learning allows us to study according to our } \\
\text { timetable and to assess ourselves any time }\end{array}$ & $\begin{array}{l}\text { psycho cognitive Register } \\
\text { prescribed function }\end{array}$ & Flexible schedules & + \\
\hline
\end{tabular}

\section{Discussion}

In many studies conducted in Europe and North America, the dropout rates in university distance learning vary between 30 and $80 \%$ (Bourdages, 2001 \& Audet, 2008). Under these conditions, a dropout rate of $50 \%$ is about average and can be considered as acceptable. In our case, a rate of over $25 \%$ is considered high because we are in a context of continuing education.

In the case under study, the interpretation registers are essentially psycho-cognitive, as opposed to the study by Brillet et al. (2010) devoted to the introduction of skills management software in a company, and wherethese registers were essentially socio-political. Indeed, in the latter case, the innovation was politically charged and employees suspected general management of wanting to further strengthen automation of skills management and then lay-off workers. However, in the case under study, e-learning appears mainly as a technical instrument for the implementation of a continuing education activity already outsourced, and does not constitute a threat to jobs.

In a recent article on e-learning in Sub-Saharan Francophone Africa, Dossou (2010) contends that among the factors of ownership, motivation and coaching are the most significant, because they are more directly related to a learner's decision to persevere or to dropout. In our case, we arrived at similar conclusions with the argument of incentives to arouse greater employee motivation for e-learning. Moreover, the human resource managers interviewed, suggested the inclusion of training in the career goals of employees in order to better motivate them.

According to Thieffry (2010), it has been established that most companies that choose to experiment e-learning beginning with office software have failed, one of the reasons being that the training is perceived as a "comfort " activity with no real use and not compulsory. The same phenomenon applies to the case studied here. Indeed employees had no difficulty in using the online platform during and afterthe ERP face-to-face training sessions. 
The reason for such success in online support and follow-up is that ERP training was strongly linked to their professional activities.

\section{Conclusion}

The purpose of our research was to determine the key factors that underpin successful introduction of e-learning on corporate intranet as part of continuing education. It emerged that only ownership can be used to measure the success or failure of such an initiative. Given the importance of ICTs in e-learning, we adopted Davis' theoretical model on technology acceptance intention, which constitutes the first phase of ownership. We also deemed it necessary to supplement the model with factors pertaining to incentives and awareness. It became clear that awareness is the dominant variable that fosters the intention to accept e-Learning in a company.

With regard to phase two of ownership that relates to effective implementation of e-learning, we adopted Brillet's model and supplemented it with organizational measures. It emerged very clearly that in the context of restricted access via corporate intranet, there are specific organizational steps the company must take to ensure the success of e-Learning, failing which the project is likely to abort regardless of whatever infrastructure, equipment and contents mediation arrangements.

In conclusion, organizational factors have emerged in the theoretical framework as key factors to success in e-Learning on a company's intranet, both for acceptance intention and for effective implementation. These theoretical considerations were confirmed by the study conducted in a company in Cameroon.

The predominance of organizational aspects among the factors underlying ownership of e-learning on corporate intranet is quite understandable. Indeed, having to access resources only from workstations installed in company sites, is a major constraint and a source of potential conflict between e-Learning and professional activities. Accordingly, organizational steps must be taken at all stages of ownership to ensure proper awareness raising, easy access to resources and, above all, compatibility between routine professional activities and those connected with online training. This especially implies a re-adjustment of schedules to avoid work overload.

\section{References}

Audet. L. (2008). Recherche sur les facteurs qui influencent la persévérance et la réussite scolaire en formation à distance. Rapport de Recherche. Réseau d'Enseignement Francophone à Distance du Canada, Montréal. Retrieved from http://bv.cdeacf.ca/record.php?record=19210996124910381789

Bourdages, L., \& Delmotte, C. (2001). La persistance aux études universitaires à distance. International Journal of E-Learning \& Distance Education, 16(2), 23-36. http://www.ijede.ca/index.php/jde/article/view/176/353

Brillet, F. et al. (2010). E-RH et Outils: l'appropriation en questions.Working Paper. Retrieved from http://reseaucompetences.fr/system/files/IAE_E-RH\%20et\%20outils\%20_\%201\%27appropriation $\% 20 \mathrm{en} \% 2$ Oquestions.pdf

Davis F. D., Bagozzi, R. R., \& Warshaw, P. R. (1989). User acceptance of computer technology: a comparison of two theoretical models. Management Science, 35(8), 982-1003. http://dx.doi.org/10.1287/mnsc.35.8.982

Demissy, B. (2003). Les difficultés d'appropriation des NTIC par les acteurs de l'entreprise: quelle contribution possible de la fonction «ressources humaines». Actes du 14è Congrès de l'AGRH. Grenoble. Tome 2, p. 901-919. Retrieved from www.reims-ms.fr/agrh/docs/actes-agrh/pdf-des.../2003demissy039.pdf

Dossou, A. K. D. (2010). Persévérance et abandon des apprenants à distance en Afrique subsaharienne francophone: quelques pistes de recherche. Frantice.net, No.1, 42-55. Retrieved from www.frantice.net/docannexe.php?id=167

Gagnon, M. P. (2003). Déterminants psychosociaux et organisationnels de l'adoption des technologies de télémédecine dans le Réseau québécois de télésanté élargi (RQTE). Thèse de doctorat en en santé communautaire. Université Laval. Faculté des Sciences Infirmières et Faculté de Médecine. Retrieved from http://theses.ulaval.ca/archimede/fichiers/21408/21408.html

Gagnon, Y. C. (2012). L'étude de cas comme méthode de recherche. Presses de l'Université du Québec. 2ème édition.

Lauzon, N. (2003). E-learning, pratiques et politiques organisationnelles en entreprise. Distances et Savoirs, $1(4), 471-488$.

Legris, P. et al. (2003). Why do people use information technology ?A critical review of the technology $\begin{array}{llll}\text { acceptance model. Information and } & \text { Management, 40, }\end{array}$ http://dx.doi.org/10.1016/S0378-7206(01)00143-4 
Lorino, P. (2002). Vers une théorie pragmatique et sémiotique des outils appliquée aux instruments de gestion. Working Papes, ESSEC, No. 02015. Retrieved from http://pfleurance.hautetfort.com/list/seminaire-7-1-intelligence-strategique-en-gestion/4140115640.pdf

Massaro, T. (1993). Introducing physician order entry at a major academic medical center: Impact on Organizational Culture and behavior. Academic Medicine, 68(1), 20-25. http://dx.doi.org/10.1097/00001888-199301000-00003

Nganmini, A. G. B. (2009). La mesure de la qualité perçue d'un dispositif de e-learning. Thèse de doctorat en sciences de gestion. Université Nancy 2. Ecole Doctorale Sciences Juridiques, politiques, Economiques et de Gestion. Retrieved from docnum.univ-lorraine.fr/public/NANCY2/doc430/2009NAN22004.pdf

OECD. (2003). Les TIC et les performances au niveau de l'entreprise, dans OCDE, Les TIC et la croissance économique: Panorama des industries, des entreprises et des pays de l'OCDE, Éditions OCDE. Retrieved from browse.oecdbookshop.org/oecd/pdfs/free/9203032e.pdf

Pang-Ning, T. et al. (2006). Introduction to Data Mining. Pearson Addison Wesley, New York. Retrieved from http://www-users.cs.umn.edu/ kumar/dmbook/index.php

Proulx, S. (2005). Penser les usages des TIC aujourd'hui : enjeux, modèles, tendances. in Lise Vieira et Nathalie Pinède, éds, Enjeux et usages des TIC: aspects sociaux et culturels, t. 1, Presses universitaires de Bordeaux. Bordeaux, $\quad$ p. 7-20. $\quad$ Retrieved from http://sergeproulx.uqam.ca/wp-content/uploads/2010/12/2005-proulx-penser-les-usa-43.pdf

Szajna, B. (1994). Software Evaluation and choice: predictive validation of the technology acceptance instrument. MIS Quarterly, 18(3), 319-324. http://dx.doi.org/10.2307/249621

Thieffry, C. H. (2010). Le choix du premier module e-Learning n'est pas important, il est vital. E-Learning Propos, Le premier Module. Retrieved from www.elearning-propos.com

Tremblay, D., De Sève, G., \& Monique, K. (2005). Les obstacles à la formation au sein des petites et moyennes entreprises : une comparaison de divers types de formation dans les secteurs du commerce de détail, ainsi que du tourisme et de l'hôtellerie. Rapport sur les organisations du secteur du tourisme et de l'hôtellerie. Notes de recherches de la Chaire Bell en technologies et organisation du travail. Retrieved from https://depot.erudit.org/id/002407dd

Venkatesh, V. (2003). User acceptance of information technology, toward a unified view. MIS Quarterly, 27(3), 425-478.

\section{Appendix A}

\section{The Classification Technique}

Let us consider $\mathrm{N}$ entities, each of which has two attributes $\mathrm{X}$ and $\mathrm{Y}$. We want to measure the impact or the explanatory power of $\mathrm{X}$ over $\mathrm{Y}$. We assume that $\mathrm{X}$ has $\mathrm{n}$ possible values $\mathrm{x}_{1}, \ldots, \mathrm{x}_{\mathrm{n}}$ and $\mathrm{Y}$ has $\mathrm{m}$ possible values $\mathrm{y}_{1}, \ldots, \mathrm{y}_{\mathrm{m}}$. For any $\mathrm{x}_{\mathrm{i}}$ value of $\mathrm{X}$, we consider the entities having the value $\mathrm{x}_{\mathrm{i}}$ for the $\mathrm{X}$ attribute. These entities have a distribution represented by a probability vector $P_{i}=\left(p_{i 1}, p_{i 2}, \ldots p_{i m}\right)$. The explanatory power of $X$ is maximum for the value $\mathrm{x}_{\mathrm{i}}$ if all entities that have that value for the $\mathrm{X}$ explanatory attribute, have the same value for the attribute explained $Y$. This occurs when $\mathrm{P}_{\mathrm{i}}$ has a component equal to 1 , all others being zero. In the general case, the explanatory power of $x_{i}$ can for example be measured by $I\left(x_{i}\right)=\max _{j} p_{i, j}($ Pang-Ning Tan et al, 2006).

The explanatory power of $X$ over $Y$ is given by the weighted sum $I\left(x_{i}\right) \cdot N_{1}+I\left(x_{2}\right) \cdot N_{2}+\ldots+I\left(x_{n}\right) \cdot N_{n}$, where $N_{i}$ denotes the number of entities with $x_{i}$ value for the attribute $X$. Assuming that for every value $x_{i}$, the predicted value for $\mathrm{Y}$ is the majority value among the values taken by $\mathrm{Y}$, this index corresponds to the number of entities for which $\mathrm{Y}$ is correctly predicted when using $\mathrm{X}$ as an explanatory variable.

For example, consider $\mathrm{N}=6$ and two attributes $\mathrm{X}$ and $\mathrm{Y}$, each with three possible values:,,-+++ . Assume that for $X$ the values are $\left(a_{1}, a_{2}, a_{3}, a_{4}, a_{5}, a_{6}\right)=(-,++,++,-,-,-)$, and for $Y$ the values are $\left(b_{1}, b_{2}, b_{3}, b_{4}, b_{5}, b_{6}\right)=(++$, $+,++,+,-,-)$. It follows that :

- for $\mathrm{x}_{1}=-$, the values of $\mathrm{y}$ are,,,+++-- , which corresponds to $\mathrm{P}_{1}=(2 / 4,1 / 4,1 / 4)$ and $\mathrm{N}_{1}=4$. Thus $\mathrm{I}\left(\mathrm{x}_{1}\right)=$ $2 / 4$

- for $\mathrm{x}_{2}=++$, the values of $\mathrm{y}$ are,+++ , which corresponds to $\mathrm{P}_{2}=(0,1 / 2,1 / 2)$ and $\mathrm{N}_{2}=2$. Thus $\mathrm{I}\left(\mathrm{x}_{2}\right)=1 / 2$ 
The explanatory power of $\mathrm{X}$ over $\mathrm{Y}$ is thus equal to $4 . \mathrm{I}(-)+2 \cdot \mathrm{I}(++)=3$. This corresponds to the fact that for $\mathrm{x}=$ '-', the prediction for $Y$ is '-' and we therefore have two well predicted elements, and for $\mathrm{x}=$ ' ++ ' , the prediction for $\mathrm{Y}$ is ' + ' or ' ++ ' and only one element is correctly predicted.

\section{Copyrights}

Copyright for this article is retained by the author(s), with first publication rights granted to the journal.

This is an open-access article distributed under the terms and conditions of the Creative Commons Attribution license (http://creativecommons.org/licenses/by/3.0/). 